\title{
An overview of seismic ground response methods over the world and their applications in Vietnam
}

\author{
G.K. Trung, N.D. Vinh, 2021 \\ Faculty of Physics, University of Science, Vietnam National University, \\ Hanoi, Vietnam
}

Received 24 November 2020

\begin{abstract}
The estimation of the impact of earthquakes on buildings and mega structures in large urban areas is of extremely importance. That is why it always gets attentions from construction planners and policy makers who are concerned about construction rules. When earthquake occurs, the vibration is transferred to sites. Although the vibration intensity is at first not too strong, the motion probably becomes stronger and lasts longer under special conditions of the local site. Two famous examples for these effects occurred in Mexico City in 1985 and in Taiwan in 1999. There are a number of approaches to this problem, such as evaluations based on seismic field observations, the microtremor method, the method using the weak motion data, the method using the strong motion data, the one-dimensional wave propagation method or the three dimensional wave propagation method with simulation etc. In this paper, we will give an overview and discuss about the advantages and the disadvantages of the methods that have been commonly applied in the world. We also present the application of these methods in studies carried out in Vietnam in general and in particular, in Hanoi city. We found that the studies for Hanoi city were mainly carried out in the western areas of Hanoi and a few positions in the urban districts. In addition, the authors only gave comments about and assessments of the shear wave velocity, and classified the ground type without a detailed map of local site effects for the entire area of Hanoi. In order to obtain a full site effects evaluation for Hanoi city, future studies should focus on the application of 1D analysis for the central area of Hanoi city and combining 1D analysis with 2D or 3D to give a better picture about the impact of local site effects. This hybrid approach is necessary in order to compare and verify the data obtained by the empirical and the analytical methods. On the other hand, many problems need to be addressed, for instance, the construction of a detailed 3D geological model for Hanoi, the calculation of the dominant periods and the amplification of the local soil conditions for the urban areas.
\end{abstract}

Key words: amplification, overview, site effects, strong ground motion, site conditions.

1. Introduction. There have been many research over the world about local site response when earthquakes happened. The earthquakes collapse buildings, damage the bridges and tunnels, cause strong ground motion and several effects such as landslides, soil liquefactions or amplifying vibrations. When earthquake occurs, the vibration is transferred to sites. Although the vibration intensity is at first not too strong, the motion probably becomes stronger and lasts longer under special conditions of the local site. Two famous examples for these effects occurred in Mexico City in 1985 and in Taiwan in 1999. In the first example, the earthquake with 8.1 Richter (Ms) magnitude occurred in Michoacan, which is around $400 \mathrm{~km}$ far from the Mexico city, but it caused the collapse of 317 highrise buildings, ten thousands of casualties and a total loss of up to 4 billion of US dollars 
there [Anderson et al., 1986; Beck, Hall, 1986; Moreno Murillo, 1995]. Because silt and clay sediments are the main deposits underneath the ground in downtown area of Mexico City, the tremor has been enhanced in the earthquake. The second example is the Chi Chi earthquake that happened in Taiwan in 1999 $(M w=7.6, M l=7.3)$. Its epicenter is $160 \mathrm{~km}$ from Taipei. Theoretically, shocks did not ably exceed magnitude 6, however the actual intensity recorded in Taipei was magnitude 8 and the soft surface sediments not only amplify the ground motions but also prolong the shaking duration [Shin, Teng, 2001; Fletcher, Wen, 2005]. The reason for these changes are mostly due to the local site conditions.

In the past decades, this problem has been widely studied by many researchers all over the world [Brady, 1966; Trifunac, Brady, 1975; Whitman, 1973; Whitman et al., 1997; Aki, Irikura, 1991; Calvi et al., 2006; Sánchez-Sesma, Crouse, 2015; Trifunac, 2016] as well as in Vietnam [Xuyen et al., 1996; Phuong, 2002; Son, 2003; Nguyen, 2002; Nguyen et al., 2012; Thuy et al., 2004; Bac et al., 2011]. There are a number of approaches to this problem, such as evaluations based on seismic field observations, the microtremor method, the method using the weak motion data, the method using the strong motion data, the one-dimensional wave propagation method or the three dimensional wave propagation method with simulation etc. In this paper, we will give an overview of the methods that have been commonly applied in the world and present their application in studies carried out in Vietnam in general and in particular, in Hanoi city.

\section{An overview of methods used to evalu- ate the effect of local site conditions on the strong-motion.}

\subsection{Empirical Methods.}

2.1.1. Method based on field observations. By surveying the earthquake damage data in a city, it is possible to divide that city into zones with different seismic hazard levels. A detailed field observation of the range of shock caused by the earthquakes can help seismic microzoning [Kagami et al., 1988, 1995]. This type of approach has been applied since the early years of the 20th century in Japan [Mogi, 1995].
Despite many difficulties in converting vibration intensity data to quantitative design parameters, this method is currently used in many parts of the world, for example, Japan, Mexico, Chile, Peru, Italy, Greece, France etc. Recently, many works in Europe [Hill, Rossetto, 2008], China [Zhao et al., 2009], Spain [Romão et al., 2013], Nepal [Malla et al., 2019] have provided a lot of useful informations for the design of earthquake resistance structures and for seismic vulnerability classification. It also has become the starting point for many earthquake prediction methods today.

2.1.2. Methods using microtremor seismic data. Microtremor is the term denoting ground oscillation produced by natural environment or ambient noise, such as wind, waves, transportations, industrial plants etc. The vibrations are recorded by high-sensitivity seismic devices. Microtremor spectral method is one of the crudest methods. It mainly determines the frequency at the maximum amplitude of the wave of the average spectrum of pure seismic micro waves. Japanese scientists believe that the spectral characteristics of seismic microtremor show some relationship with the ground geological conditions. For example, a dominant period of microtremor less than $0.2 \mathrm{~s}$ is an index of solid or rocky soil, while longer periods indicate thicker and more porous sediments.

The frequencies at these maximum amplitudes have also been explained as having relations with the basic resonant frequencies of the survey location. Experimental surveys in locations such as Mexico City [Lermo et al., 1988] (Fig. 1), Los Angeles [Yamanaka et al., 1993], Taiwan [Wen, Huang, 2012] and in many other locations in Japan have given clear evidence for the same conclusion in case of long periods $(T>1 \mathrm{~s})$.

By this method, the effect of local site conditions is determined by the spectral ratio of seismic bands received at the study site and the reference site. The reference site is chosen so that it is close enough to the study site to ensure that the difference between the sites is due to the local site condition rather than the difference of the sources of noise or transmission. Furthermore, the reference site should 


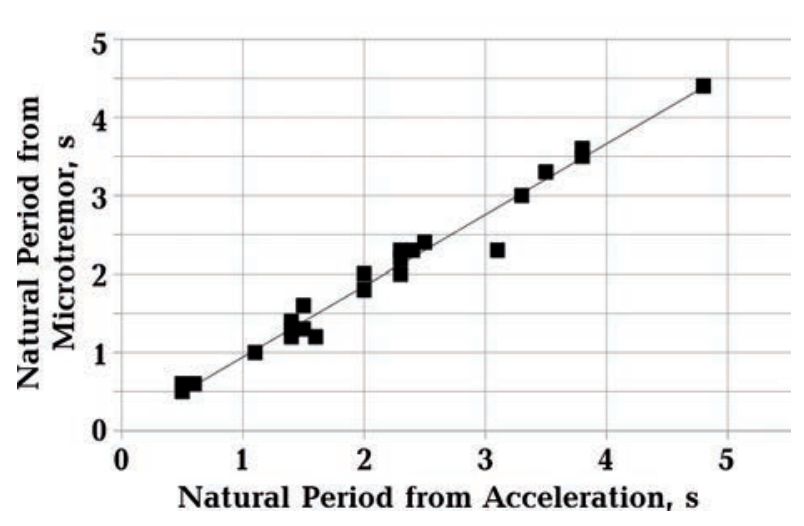

Fig. 1. Natural period estimated from microtremor spectra versus natural period obtained from strong ground motion data [Lermo et al., 1988].

be located on the horizontal bedrock which has not been weathered.

Horizontal-to-Vertical Spectral Ratio(HVSR, or Nakamura method) is the ratio between the horizontal component and the vertical component of the Fourier spectrum of microtremor. In 1989, Nakamura argued that the $H / V$ ratio allows to evaluate the reaction of local site to $S$-waves, providing reliable results not only for resonance frequencies but also for the corresponding amplifications. This is based on the interpretation of seismic waves, such as Rayleigh waves, spreading in a single layer (loose soil layer) situated on space above the bedrock. In the frequency domain, microtremor can be expressed in four types of amplitude spectra: the Fourier amplitude spectra for the vertical and the horizontal components of oscillation at the surface of the soil layer $\left[V_{S}(w)\right.$, $\left.H_{S}(w)\right]$, and the Fourier amplitude spectra for the vertical and the horizontal components at the surface of the bedrock $\left[V_{b}(w), H_{b}(w)\right]$.

Through seismic records obtained in drill holes, Nakamura has empirically come to the following equations: $\frac{H_{b}(w)}{V_{b}(w)}=1$, and $S_{m}(w)=\frac{H_{S}(w)}{V_{S}(w)}$, where $S_{m}(w)$ represents the effect of local site conditions.

Based on these equations, Nakamura suggested that the effect of the local site condition could be determined by the ratio of the amplitude spectrum between the horizontal and the vertical components of microtremor. Similar results were also obtained by KazuohSeo in a study on microtremors in Fukui basin in Japan [Seo et al., 2000]. Up to now, the Nakamura method is considered one of the cheapest, fastest and most suitable method for quite reliable calculation of the fundamental frequency of the porous sediments. Nakamura [2019] added the remark that «the Nakamura method to estimate not only the resonance frequency and amplification factor of a surface layer using HVSR at ground surface but also the resonance frequency and the amplification factor of both buildings and ground using HVSR at the top of a building».

In the development of the microtremor methodology, there are two different approaches. In one approach, which is described above and considered the standard tool for calculating the natural site period, data from a single observation station are used. The other approach, named the spatial autocorrelation method (SPAC method), uses data from a group of stations. It was introduced by Aki in 1957 and developed by other scientists [Aki, 1957; Henstridge, 1979; Okada, 1998, 2006; Haney et al., 2012]. The SPAC method was shown to be effective for determining shear wave velocity structures of sediments and site characterization [Kudo et al., 2002; Apostolidis et al., 2004; Chávez-García et al., 2005].

2.1.3. Methods using the weak motion data. Weak motion data are recorded from small or medium seismic events of natural or manmade earthquakes, such as earthquakes with small magnitude, aftershocks of large earthquakes, mining blasts or nuclear weapons tests. The data recorded by traditional highsensitivity digital devices can be used in determining ground effects. The most challenging difficulty in using this kind of data is the elimination of the effects of sources and transmission [Field, Jacob, 1995]. Two methods frequently used to solve this problem are:

- The reference-site method (the Standard Spectral Ratio technique, SSR): This method has been introduced by Borcherdt since 1970 and is widely used until now. It is basically similar to the spectral ratio method mentioned in section 2.1.2, but differs from that by the use 
of data from a big enough network of stations with the assumption that the distance between two stations is closer than the source-to-site distance [Borcherdt, 1970, 1994; Borcherdt , Glassmoyer, 1994; Andrews, 1986; Field, Jacob, 1995; Tramelli et al., 2010; Priolo et al., 2019].

- The non-reference-site method: This method is used in cases when reference locations are not available [Steidl et al., 1996]. In this method, the response of the ground is determined by obtaining the spectral ratio between the horizontal component and the vertical component of the shear waves. It is principally a combination of the method that Langston [1979] used to determine the velocity structure of the Earth's crust from the spectral ratio between the horizontal and the vertical components (HVSR) of $P$-waves and the Nakamura's method [1989, 1996]. This technique had been initially used by Lermo and Chávez-Garcia [1993] to successfully evaluate site effects for three different cities in Mexico: Oaxaca Oax., Acapulco Gro., and Mexico City from only one station. However, further experiments have tested and shown that this method is only applicable for porous ground, hence it may not be suitable for other types of site conditions [Field, Jacob, 1995; Bard, 1999].

2.1.4. Method using the strong motion data. With the development of strong motion network stations in the world, many cities (Los Angeles, Mexico, Taipei, and Tokyo) can use the method in Section 2.1.3 with the strong motion data instead of the weak one. In the case of Mexico City, the network of stations there recorded at least one event per year allowing to obtain results with sufficient reliability and details to perform seismic microzonation.

In Japan, the nation-wide strong motion network is up to nearly 2000 stations (Fig. 2) distributed all over the country. Since early 1990, a network of strong motion stations has been established in a large number of areas in Taiwan. It has been used for monitoring earthquake in real time since 1995 [Wu et al., 1997, 2019]. The data obtained from these networks are not only deployed in construction projects and urban planning but also efficiently sup- port early warning systems in Japan, Taiwan and other countries.

2.1.5. The empirical relationship based on surface geology. The effects of the porous sediments on seismic response are often observed. The number of observations allows researchers to develop the empirical relationships between surface geology and its effects on earthquake vibrations. Table 1 describes the empirical relationship between the surface geology and the vibration intensity increase proposed by Medvedev [1962]; Evernden and Thomson [1985]; Kagami et al. [1988]; Astroza and Monge [1996]. Here the correlation given by Mevedev has been widely used in Eastern European countries for earthquake zoning studies, while the correlations by Evernden and Thomson are used in Western Europe used in Western Europe for predictive studies. Although these correlations are based on data from certain areas (California, Chile, Japan, Middle Asia), they will be applicable to anywhere in the world if corrections to the differences between the JMA, MM or MSK scales are made. This solution is now being used to construct the level damage of earthquakes in the future and most of the curves of hazard assessment to buildings and other works are given as a function of vibration intensity.

In many cases, when the Intensity Increments of local site effect is not clearly seen, we can consider the relative amplification factor for the corresponding geological units (Table 2). However, the derivation of these empirical relations are not simple because the amplification factor for each geological unit is not all determined in the same way.

2.2. Numerical Approach. When the geotechnical characteristics of the site or region are known, in principle, the local site effects can be determined by numerical analysis. The common base is the equation of wave propagation in the soil and rock environment. Various models have been suggested in these numerical analysis. For example, we must pay attention to the forms of the incoming wave field (far field, near field, body wave, surface wave); structural shapes (1D, 2D, or 3D); Mechanical reaction of Earth's material under different conditions: flooded environment, 


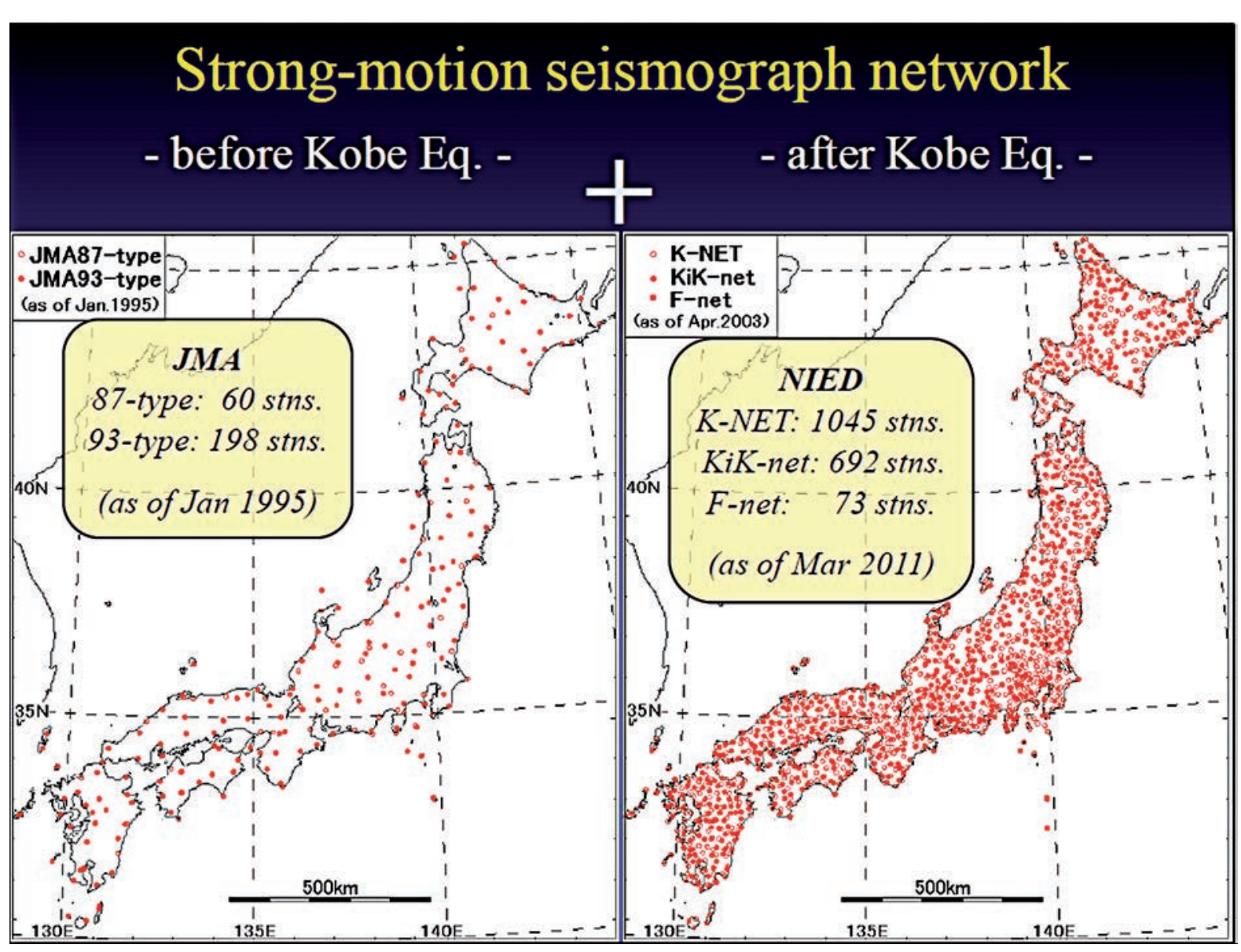

Fig. 2. Japan Strong Ground motion stations [Okada, 2013].

liquid environment, elasticity etc. are also included in the models.

In fact many problems exist. For examples, numerical approach requires high quality input data and detailed geotechnical and geophysical surveys for the research positions which increase the cost of construction.

2.2.1. Approximate Methods. As mentioned above, the magnification on porous soil is related to resonant effects, the factors shown in the frequency domain as peaks of the Fourier transform function. Using a simple numerical method, we can determine the fundamental period of the ground $\left(T_{0}\right)$ and the corresponding amplification $A_{0}$. The calculation will be performed if only one layer is considered above bedrock. It is necessary to know the $S$-wave velocity and the thickness of the surface layer to identify the $T_{0}$ and the $A_{0}$ which requires wave velocity in the bedrock and the damping coefficient of the sediments.
With locations on the multi-layer structure, the simple calculations can give good results on the fundamental period $T_{0}$. Under normal conditions, these calculations can be done using the formula given by [Dobry et al., 1976], which are summarized in Table 3.

In Table 3, the method 1, 2, 4 can be assigned to a category because they all shows the same behavior. The errors of this group is about 20 percent. Although the method number 3 is often used in practice because it is kindly simple to obtain the sum of layers' period, its errors are larger than 25 up to 30 percent.

The Methods 5, Simplified Version of the Rayleigh Procedure, is the best methods which produces an error less than 10 percent for calculating the period for all profiles and are recommended for practical use.

Up to now the methods of estimating fundamental periods from shear-wave profiles have been developed and discussed in many 
T a b l e 1 . Intensity increment for each geological unit

\begin{tabular}{|c|c|c|}
\hline Geological unit & $\begin{array}{l}\text { Intensity } \\
\text { incre- } \\
\text { ments }\end{array}$ & References \\
\hline Granites & 0 & \multirow{9}{*}{$\begin{array}{l}\text { MSK Scale } \\
\text { [Medvedev, } \\
\text { 1962] }\end{array}$} \\
\hline $\begin{array}{l}\text { Lime stone sand } \\
\text { stone shale }\end{array}$ & $0.2-1.3$ & \\
\hline Gypsum, Marl & $0.6-1.4$ & \\
\hline $\begin{array}{l}\text { Coarse material } \\
\text { ground }\end{array}$ & $1.0-1.6$ & \\
\hline Sandy ground & $1.2-1.8$ & \\
\hline Clayey ground & $1.2-2.1$ & \\
\hline Fill & $2.3-3.0$ & \\
\hline $\begin{array}{l}\text { Moist ground } \\
\text { (gravel, sand, } \\
\text { clay) }\end{array}$ & $1.7-2.8$ & \\
\hline $\begin{array}{l}\text { Moist fill and soil } \\
\text { ground (marsh) }\end{array}$ & $3.3-3.9$ & \\
\hline $\begin{array}{l}\text { Granitic } \\
\text { and } \\
\text { metamorphic } \\
\text { rocks }\end{array}$ & 0 & \multirow{6}{*}{$\begin{array}{l}\text { MM Scale } \\
\text { [Everden, } \\
\text { Thomson, } \\
\text { 1985] }\end{array}$} \\
\hline Paleozoic rocks & 0.4 & \\
\hline $\begin{array}{l}\text { Early Mesozoic } \\
\text { rocks }\end{array}$ & 0.8 & \\
\hline $\begin{array}{l}\text { Cretaceous to } \\
\text { Eocene rocks }\end{array}$ & 1.2 & \\
\hline $\begin{array}{l}\text { Undivided } \\
\text { Tertiary rocks }\end{array}$ & 1.3 & \\
\hline $\begin{array}{l}\text { Oligocene to } \\
\text { middle Pliocene } \\
\text { rocks }\end{array}$ & 1.5 & \\
\hline
\end{tabular}

research [Zhao, 1996; Hadjian, 2002; Motazedian et al., 2011; Vijayendra et al., 2015; Urzua et al., 2017; Wang et al., 2018]. They are adjusted to a pocket calculator and easily performed on spreadsheet. However, those methods are no longer valid in the case of a thin layer of porous soil which is deep and covered by harder and much thicker layers.

\begin{tabular}{|c|c|c|}
\hline Geological unit & $\begin{array}{c}\text { Intensity } \\
\text { incre- } \\
\text { ments }\end{array}$ & References \\
\hline $\begin{array}{c}\text { Pliocene- } \\
\text { Pleistocene rocks }\end{array}$ & 2.0 & \multirow{4}{*}{$\begin{array}{l}\text { MM Scale } \\
\text { [Everden, } \\
\text { Thomson, } \\
\text { 1985] }\end{array}$} \\
\hline $\begin{array}{c}\text { Tertiary volcanic } \\
\text { rocks }\end{array}$ & 0.3 & \\
\hline $\begin{array}{c}\text { Quaternary } \\
\text { volcanic rocks }\end{array}$ & 0.3 & \\
\hline $\begin{array}{l}\text { Alluvium } \\
\text { (water table) } \\
\quad<10 \mathrm{~m} \\
10-30 \mathrm{~m} \\
>30 \mathrm{~m}\end{array}$ & $\begin{array}{l}3.0 \\
2.0 \\
1.0\end{array}$ & \\
\hline $\begin{array}{c}\text { Talus } \\
\text { and Andesite }\end{array}$ & 0 & \multirow{8}{*}{$\begin{array}{l}\text { JMA intensity } \\
\text { scale [Kagami } \\
\text { et al., 1988] }\end{array}$} \\
\hline Gravel & 0.2 & \\
\hline River Deposits & 0.4 & \\
\hline Volcanic Ash & 0.5 & \\
\hline Sandy Silts & 0.7 & \\
\hline Clay Silts & 0.8 & \\
\hline Silt & 1.0 & \\
\hline Peat & 0.9 & \\
\hline Granitic rock & 0 & \multirow{5}{*}{$\begin{array}{c}\text { MM scale } \\
\text { [Astroza, } \\
\text { Monge, 1996] }\end{array}$} \\
\hline $\begin{array}{c}\text { Volcanic } \\
\text { pumicite ashes }\end{array}$ & $1.5-2.5$ & \\
\hline Gravel & $0.5-1.0$ & \\
\hline Colluvium & $1.0-2.0$ & \\
\hline $\begin{array}{l}\text { Lacustrine } \\
\text { deposits }\end{array}$ & $2.0-2.5$ & \\
\hline
\end{tabular}

2.2.2. Method of solving the wave propagation in one-dimensional environment. Nowadays we have a lot of methodologies to estimate the response of local soil conditions when earthquakes happen. With one-dimensional (1D) analysis we have several famous programs such as: SHAKE91, SHAKE2000, DEEPSOIL, ERRA, FLAC or Strata. The foun- 
T a b l e 2. Relative site amplification for each geology

\begin{tabular}{|c|c|c|}
\hline Geological unit & $\begin{array}{c}\text { Relative } \\
\text { ampli- } \\
\text { fication } \\
\text { factor }\end{array}$ & References \\
\hline Bay mud & 11.2 & \\
\hline Alluvium & 3.9 & \\
\hline Santa Clara Formation & 2.7 & [Borcherdt, \\
\hline Great Valley sequence & 2.3 & Gibbs, 1976] \\
\hline Franciscan Formation & 1.6 & \\
\hline Granite & 1.0 & \\
\hline Peat & 1.6 & \\
\hline Humus soil & 1.4 & \\
\hline Clay & 1.3 & [Shima, 1978] \\
\hline Loam & 1.0 & \\
\hline Sand & 0.9 & \\
\hline Holocene & 3.0 & \\
\hline Pleistocene & 2.1 & \\
\hline $\begin{array}{l}\text { Quaternary volcanic } \\
\text { rocks }\end{array}$ & 1.6 & $\begin{array}{c}\text { [Midorikawa, } \\
\text { 1987] }\end{array}$ \\
\hline Miocene & 1.5 & \\
\hline Pre-Tertiary & 1.0 & \\
\hline
\end{tabular}

dation of 1D seismic analysis bases on the shear wave propagation from the bedrock up to the top horizontal layers and its main responses [Thomson, 1950; Gutenberg, Richter, 1956; Idriss, Seed, 1968; Schnabel et al., 1972; Kausel, Roesset, 1984; Kramer, 1996; Ching , Glaser, 2001]. The output of analysis will show the effect of soil resonance with strong ground motion in the investigated area which play an important role in civil engineering. The results from these methods reasonably agrees with field observations, hence they become a foundation for evaluating responses within soil deposits and the characteristics of ground surface motions.

In one dimension, analysis can be categorized in to three types which are linear, equivalent-linear and non-linear analysis. The linear and equivalent-linear analysis are carried out in the frequency domain while the non-linear analysis is executed in the time domain.

When using program (SHAKE or DEEPSOIL) to evaluate the site response in one-dimensional environment, the shear-wave velocity and ground type are the crucial input data in the calculating process. On the other hand, the ground type and $V_{S, 30}$ are also employed in structure design for earthquake resistance. With an investigated area having detailed information about geology and boreholes, we are able to calculate the $V_{S, 30}$ (the average shear wave velocity) and the ground type. The Vietnam Building Code [2012], International Buiding Code [2009] and Eurocode 8 [2004] have similar structure design for earthquake resistance. Following Eurocode 8, the ground conditions and ground type are described in Table 4.

Where $V_{S, 30}$ should be computed in the following expression: $V_{S, 30}=\frac{30}{\sum_{i=1, N} h_{i} / v_{i}}$

$h_{i}$ is the thickness (in meters); $v_{i}$ is shear-wave velocity of the $i$-th formation or layer, in a total of $N$, existing in the top $30 \mathrm{~m}$ from the surface.

Many questions have been raised about the feasibility of the more than 50-year-old theory. In fact, this theory is still appropriate for earthquake response of horizontal layers in the modern analysis [Groholski et al., 2015, 2016; Fiorentino et al., 2018; Yamin et al., 2018, Stanko et al., 2019]. The reason is that due to the simplicity of the program, the input and output data are the text file or spreadsheet and more crucially the working time of program to get site response is quite fast (just in seconds).

Alot of groups continue to develop 1D programs supporting all types of analysis such as DEEPSOIL (2020), PLAXIS (2020), Strata (2019) etc. However, in many case, when the analysis need more details, the modeling requires performing two or three dimensional calculation for more accuracy. We can see the basin effect, edge effects, effects of strong lateral discontinuities with 2D or 3D simulations which also exhibit the higher peak and longer duration compared with $1 \mathrm{D}$ results (Fig. 3).

2.2.3. Method of solving the wave propagation in $2 D \& 3 D$ environment. It is shown that 
T a b l e 3. Summary of Approximate Methods

\begin{tabular}{|c|c|c|c|}
\hline $\begin{array}{l}\text { Method } \\
\text { No }\end{array}$ & Description & Procedure for soil period, $T$ & References \\
\hline 1 & $\begin{array}{l}\text { Weighted average of } \\
\text { velocities of layers }\end{array}$ & $\begin{array}{c}\bar{V}=\frac{1}{H_{i}} \sum_{i=1}^{n} V_{i} H_{i} \\
T_{0} \cong T_{1}=\frac{4 H}{\bar{V}}\end{array}$ & $\begin{array}{c}\text { [Schnabel et al., } \\
\text { 1972] }\end{array}$ \\
\hline 2 & $\begin{array}{l}\text { Weighted average of } \\
\text { modulus of layers }\end{array}$ & $\begin{array}{c}\bar{G}=\frac{1}{H_{i}} \sum_{i=1}^{n} G_{i} H_{i} \\
\bar{\rho}=\frac{1}{H_{i}} \sum_{i=1}^{n} \rho_{i} H_{i} \\
T_{0} \cong T_{2}=\frac{4 H}{\sqrt{\bar{G} / \bar{\rho}}}\end{array}$ & $\begin{array}{l}\text { [Ambraseys, 1959; } \\
\text { Idriss, 1966] }\end{array}$ \\
\hline 3 & $\begin{array}{l}\text { Sum of periods of } \\
\text { layers }\end{array}$ & $T_{0} \cong T_{3}=\sum_{i=1}^{n} \frac{4 H_{i}}{V_{i}}$ & [Shima, 1962] \\
\hline 4 & $\begin{array}{l}\text { Equation based on } \\
\text { linear first modal shape }\end{array}$ & $\begin{array}{c}w_{4}^{2}=\left(3 \sum_{i=1}^{n} V_{i}^{2} H_{i}\right) / H^{3} \\
T_{0} \cong T_{4}=\frac{2 \pi}{\omega_{4}}\end{array}$ & [Biggs, 1964] \\
\hline 5 & $\begin{array}{l}\text { Simplified of version } \\
\text { the Rayleigh Procedure }\end{array}$ & $\begin{array}{c}\omega^{2} \approx \omega_{5}^{2}=\frac{4 \sum_{i=1}^{n} \frac{\left(H-z_{m i}\right)^{2}}{V_{i}^{2}} H_{i}}{\sum_{i=1}^{n}\left(X_{i}+X_{i+1}\right)^{2} H_{i}} \\
T_{0} \cong T_{5}=\frac{2 \pi}{\omega_{5}}\end{array}$ & [Dobry et al., 1976] \\
\hline
\end{tabular}

in many cases, the 1D-site response analysis is not accurate for the location where soil is surrounded by rock and forms a sedimentary basin. Meanwhile, 2D and 3D analysis give a better understanding about the ground seis- mic response induced by the local soil condition when earthquake happens. These effect has been intensively studied by various researchers around the world [Sánchez-Sesma, 1987; Aki, 1988, 1993; Bard, 1994; Pitarka et al., 
T a b l e 4 . Ground types [Eurocode 8 ..., 2004]

\begin{tabular}{|c|c|c|c|c|}
\hline \multirow[b]{2}{*}{$\begin{array}{l}\text { Ground } \\
\text { type }\end{array}$} & \multirow[b]{2}{*}{ Description of stratigraphic profile } & \multicolumn{3}{|c|}{ Parameters } \\
\hline & & $V_{S, 30} \mathrm{~m} / \mathrm{s}$ & $\begin{array}{l}N_{\mathrm{SPT}} \\
\text { (blows/ } \\
30 \mathrm{~cm} \text { ) }\end{array}$ & $C_{u} \mathrm{kPa}$ \\
\hline A & $\begin{array}{l}\text { Rock or other rock-like geological formation, } \\
\text { including at most } 5 \mathrm{~m} \text { of weaker material at the surface }\end{array}$ & $>800$ & - & - \\
\hline B & $\begin{array}{l}\text { Deposits of very dense sand, gravel, or very stiff clay, } \\
\text { at least several tens of metres in thickness, } \\
\text { characterised by a gradual increase of mechanical } \\
\text { properties with depth }\end{array}$ & $360-800$ & $>50$ & $>250$ \\
\hline $\mathrm{C}$ & $\begin{array}{l}\text { Deep deposits of dense or mediumdense sand, gravel } \\
\text { or stiff clay with thickness from several tens to many } \\
\text { hundreds of metres }\end{array}$ & $180-360$ & $15-50$ & $70-250$ \\
\hline $\mathrm{D}$ & $\begin{array}{l}\text { Deposits of loose-to-medium cohesionless soil } \\
\text { (with or without some soft cohesive layers), or of } \\
\text { predominantly soft-to-firm cohesive soil }\end{array}$ & $<180$ & $<15$ & $<70$ \\
\hline E & $\begin{array}{c}\text { A soil profile consisting of a surface alluvium layer } \\
\text { with vs values of type } \mathrm{C} \text { or } \mathrm{D} \text { and thickness varying } \\
\text { between about } 5 \mathrm{~m} \text { and } 20 \mathrm{~m} \text {, underlain by stiffer } \\
\text { material with } V_{S}>800 \mathrm{~m} / \mathrm{s}\end{array}$ & - & - & - \\
\hline S1 & $\begin{array}{l}\text { Deposits consisting, or containing a layer at least } 10 \mathrm{~m} \\
\text { thick, of soft clays/silts with a high plasticity index } \\
(\mathrm{PI}>40) \text { and high water content }\end{array}$ & $\begin{array}{c}<100 \\
\text { (indicative) }\end{array}$ & - & $10-20$ \\
\hline $\mathrm{S} 2$ & $\begin{array}{l}\text { Deposits of liquefiable soils, of sensitive clays, or any } \\
\text { other soil profile not included in types A-E or } S 1\end{array}$ & - & - & - \\
\hline
\end{tabular}

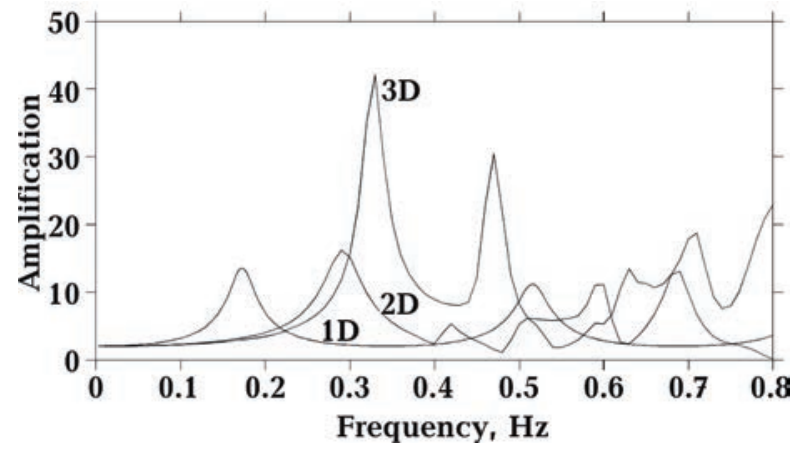

Fig. 3. Comparison of spectral responses of 1D, 2D and 3D models for a cosine-shaped basin [Bard, RieplThomas, 2000].
1998; Bielak et al., 2000; Chávez-García, 2003; Fernández, 2007; Lee et al., 2008; Narayan, 2005; Narayan, Sahar, 2014; Smerzini et al., 2011 a, b; Dhakal,Yamanaka, 2013; Frankel et al., 2014; Kamal, Narayan, 2015; Abraham et al., 2016; Hasal et al., 2018].

In sedimentary basin, a big difference has been found in velocity at the edges at which the diffraction occurs and the body waves are trapped. It causes some incident waves to travel through the basin soil as surface waves. Therefore, the basin edges can be considered assecondary seismic sources. Basin effects result in longer ground motions with an increase in low-frequency energy compared to those 
predicted by the 1D models [Kawase, 2003]. Since the surface waves are likely significant near the edges, they are the main reason for the serious damage as well as the amplification and the prolongation of the duration of ground-motion in the earthquake.

Several methodologies have been carried out to assess this effect [Bard, Riepl-Thomas, 2000; Olsen, 2000], such as analytical methods, domain-based models, ray methods and boundary-based techniques. Analytical methods are often used for very simple geometries e. g., homogeneous circular or elliptical basins [Trifunac, 1971; Wong, Trifunac, 1974]. Ray methods which are applicable only to high-frequencies are difficult to use for wavelengths comparable to the size of the heterogeneities [Bard, Riepl-Thomas, 2000]. Boundary-element techniques are the most efficient when the site under consideration consists of a limited number of homogeneous geological units. However, since the resulting system is dense, it is difficult to apply the method to highly heterogeneous medium [Herrera, 1984; Manolis, Beskos, 1988]. Although domain models are the best candidate for problems with complex geometries, they cost more CPU time and require a semi-infinite medium cutoff replaced by an artificial boundary [Bielak et al., 1999]. In general, numerical methods are very flexible and adjustable, however, they require detailed geotechnical or geophysical investigations to determine input parameters.

2.2.4. Hybrid Approach. In many cases, due to the lack of information or the limit of the approach, we need at least two analysis methods to evaluate the seismic ground response. Firstly, we can account the work of Donat Fäh [Fäh et al., 1993], in which he had introduced a new method for realistic estimation of seismic ground motion in megacities. This method combines the modal summation and finite-difference to simulate the ground motion. The numerical simulation results of the ground motion caused by the 1915 Fucino (Italia) earthquake are in good agreement with the observed distribution of destruction. This method also allows us to evaluate the local wave field from seismic events, where epicentral distance is from a few kilometers to hundreds of kilometers.

The other methods either combine the numerical earthquake models and the observation [Chávez-García et al., 2000; Chávez-García, 2003]; or compare the results from the hybrid modelling in the frequency domain with the results obtained from experimental data [Riepl et al., 2000]; or combine the finite element method with the boundary element method to solve problem of homogeneous and non-homogeneous topographic structures subjected to incident in-plane motions [Kamalian et al., 2006]; or use the stochastic method proposed by Boore [2003]; or apply the analytical model proposed by Mavroeidis and Papageorgiou [2003] to study about the bed rock and ground surface acceleration of the considered region [Ebrahimian, 2013]; or estimate seismic site amplification using microtremor measurements and HVSR analysis combined with 1D equivalent-linear site response analysis for different peak ground accelerations [Stanko et al., 2019].

\section{Case study: Applications in Vietnam} and the city of Hanoi. In recent years, various Vietnamese scientists have carried out intensive studies on hazard assessment of construction works at the hydroelectric power stations Tri An, Son La, Lai Chau etc., and seismic microzoning for cities such as Hanoi, Dien Bien, Hue, Lai Chau, Vung Tau, and Ho Chi Minh City. In particular, many studies have been implemented to evaluate the effect of strong ground motion for the Hanoi area. Several groups of Vietnamese researchers were contributing to these studies.

3.1. Applications in Vietnam. In Vietnam, the first assessment of the effect of soil conditions on strong motion was carried out in 1964 when a small earthquake zoning map of Hanoi City at a scale of 1 : 50000 was established. In this project, members of the Department of Geophysics - Office of Meteorology were using the seismic rigidity method suggested by Medvedev [1962]. It is among those practical methods which show the correlation between surface geology and seismic responses and was commonly applied in Eastern Europe. By 1996, the final report of the National project 
coded KT-ĐL 92-07 (Nguyen DinhXuyen, Nguyen Ngoc Thuy et al.) also mentioned this method in its conclusions.

After that, this method and others were used in earthquake hazard assessments for Ham Thuan and Dai Ninh hydropower plant areas, among others. A significant progress observed in these projects was that besides the qualitative conclusions, some quantitative results have also been obtained by microtremor and calculation methods. By 2002, in his master's thesis, Pham Dinh Nguyen explored in more detail the methods popularly used at that time in the world. Moreover, he has applied the SHAKE91 program to evaluate site effect for the Thang Long cement grinding plant in Ho Chi Minh City; and for the Tri An and Lai Chau hydropower plants; etc.

In the final report of the project named «Study of earthquakes prediction and ground motion in Vietnam» by [Xuyen et al., 2004], for the first-time, data on strong motion of the United State, Europe, China and the data of the 2001 Dien Bien earthquake were used with the SHAKE91 program to perform the normalized response spectra for different soil conditions in Vietnam at a distance of a few to hundreds of kilometers from the earthquake epicenters. In 2007, in the article "Microzoning map of the Dienbien city» [Son, 2007], the authors have used the Nakamura's microtremor method in combination with the use of the average shear wave velocity for the first $30 \mathrm{~m}$ from the ground to classify the ground type and obtain predominant periods and spectral peaks of Dien Bien city.

In 2012, Pham Dinh Nguyen et al. have raised the issue of the influence of the terrain on seismic ground motion. The topographic conditions on the ground tend to increase the amplitude of seismic signals for horizontal components at sites around mountain summits.

In 2017, basing on gravity data, seismic exploration and tectonic data [Minh et al., 2017] have simulated the wave propagation in 3D environment to simulate the site effect for the number 2 Tranh River hydropower dam in North Tra My, Quang Nam province. In the 3D model, the physical properties of the model as well as boundaries have been clearly defined basing on actual data. Information about the source scenario, such as coordinates, depth, magnitude of earthquake, 6 components of seismic moment and information about important faults in the studied area were considered and included in the model. With the chosen input data, the authors not only produced quantitative values of the acceleration in the region but also showed the specific characteristics of $P$-waves and $S$-waves on the simulation acceleration bands that have already been collected.

3.2. Case study for Hanoi. In the specific case of Hanoi city, due to its important position as the capital of the country and its location on the Red River fault system, it particularly attracts a great deal of attention from scientists who concentrate on the influence of the local ground conditions on strong motion. Research methodology has improved, and research activities have increased over time.

In the final report of the "Study on the seismic risk assessment for Hanoi» [Phuong et al., 2002]), the seismic code NEHRP (1997) of the United States was applied to determine the amplification factors for Hanoi city. The two projects, «Study of earthquake prediction and ground motion in Vietnam» [Xuyen et al. 2004], «Study, supplement and enhancement of the $1: 25000$ scale seismic microzonning map of the enlarged Hanoi city, development of the ground motion characteristic database in Hanoi in accordance with the map» [Thuy et al., 2004] were completed by using the seismic rigidity method, the microtremor methods, and calculation about site effects for environment of multi sedimentary layers overlying a rigid base.

N.H. Phuong et al. [2006] summarised the results of his study as follows: "Two methods with interdependent relationship were presented. The first method allows quantitatively assess the ground motions with amplification of ground shaking to account for local site conditions. The second method, using the output of the first one, allows to estimate the damage and loss caused by earthquakes for an urban area. The methods have been successfully applied to a downtown district of Hanoi. 
The wide implementation of the methods can considerably contribute to the earthquake hazard assessment and risk management, particularly the urban risk for the megacities in Vietnam».

In 2012, Vu Minh Tuan et al., used the HVSR method to analyze microtremor for some locations in Hanoi, thereby evaluating its feasibility for Vietnamese conditions.

Basing on microtremor motion observation for Hanoi area, Nguyen Tien Hung and Kuo-Liang Wen [2011] calculated the ground predominant periods by using microtremor techniques. It has been shown that the dominant frequency of the ground gradually increases from north to south and from east to west. The regions with dominant frequencies greater than $0.6 \mathrm{~Hz}$ are along the Red River, the urban area, the east and the south of the city which are dominated by near-surface thin coating.

Nguyen Anh Duong et al. [2017] conducted a seismic hazard assessment and a local site effect evaluation for Ha Dong area of Hanoi city basing on $V_{S, 30}$ parameters and Nakamura's $H / V$ spectral ratio. The map of ground dominant periods for Ha Dong district was established with a $T_{S}$ range of $0.6-1.2 \mathrm{se}$ conds. The result also shows that the PGAvalue corresponding to the 500-year return period of Ha Dong district is in the range of 0.13 to $0.17 \mathrm{~g}$. Withthe first attempt to evaluate the local site effect of Hanoi, Giang KienTrung et al. [2018] used the shear velocity and unit weight from the selected boreholes of some districts having categorization of weak soil to insert into the DEEPSOIL program. The results show that under the soil conditions of Hanoi area, the local site effect will happen if the scenario of earthquake occurs with magnitude greater than $6.0(M w)$. The realization for site amplification of Hanoi city is very important and requires more attention.

\section{Discussions and Conclusions.}

- In this paper, we have presented all methods commonly used in the world to evaluate the site effect. The methods were divided into groups for a better overview and easier choice for application.
- For each method listed in this paper we have given reviews and comments on its major advantages and disadvantages. Up to now, most recent studies on site effect often try to use two or more methods in order to verify and complement each other. The 3D model and hybrid methods are always the first choice for areas that meet the research requirements and need high level of seismic hazard assessment.

- For Vietnam, the $H / V$ method (microtremor), 1D problem and seismic survey, as well as engineering geology have been the methods mainly in use. The 3D problem has also began to come into application, but only at the stage of early trials for one place.

- Along with the development of Hanoi city, the database consisting of its borehole data, geophysical surveys, and laboratory tests has become better and more supplemented. Previous studies were mainly carried out in the western areas of Hanoi and a few positions in the urban districts. In addition, the authors only gave comments about and assessments of the shear wave velocity, and classified the ground type without a detailed map of local site effects for the entire area of Hanoi. In order to obtain a full site effects evaluation for Hanoi city, future studies should focus on the application of 1D analysis for the central area of Hanoi city and combining 1D analysis with 2D or 3D to give a better picture about the impact of local site effects. This hybrid approach is necessary in order to compare and verify the data obtained by the empirical and the analytical methods. On the other hand, many problems need to be addressed, for instance, the construction of a detailed 3D geological model for Hanoi, the calculation of the dominant periods and the amplification of the local soil conditions for the urban areas.

5. Acknowledgements. We would like to thank the Department of Seismology and the Department of Seismological Survey, Institute of Geophysics, Vietnam Academy of Science and Technology for their support, data, and documents. We also thank Dr. Le Tu Son and Dr. Pham Dinh Nguyen for his valuable comments and recommendations. G.K. Trung thanks Nafosted Grant № 103.01-2019.324 for support. 


\section{References}

Abraham, J.R., Smerzini, C., Paolucci, R., Lai, C.G. (2016). Numerical study on basin-edge effects in the seismic response of the Gubbio valley, Central Italy. Bulletin of Earthquake Engineering, 14, 1437-1459. https://doi.org/10.1007/s 10518-016-9890-y.

Aki, K. (1988). Local Site Effects on Strong Ground Motion. In Earthquake Engineering and Soil Dynamics II - Recent Advances in GroundMotion Evaluation (pp. 103-155). Park City, UT, USA.

Aki, K. (1993). Local site effects on weak and strong ground motion. Tectonophysics, 218(13), 93-111. https://doi.org/10.1016/0040-1951 (93)90262-I.

Aki, K. (1957). Space and time spectra of stationary stochastic waves, with special reference to microtremors. Bulletin of the Earthquake Research Institute, 35, 415-456.

Aki, K., \& Irikura, K. (1991). Characterization and mapping of earthquake shaking for seismic zonation. Proc. 4th International Conf. on Seismic Zonation, 1, 61-110.

Ambraseys, N.N. (1959). A note on the response of an elastic overburden of varying rigidity to an arbitrary ground motion. Bulletin of the Seismological Society of America, 49, $211-$ 220.

Anderson, J.G., Bodin, P., Brune, J.N., Prince, J., Singh, S.K., Quaas, R., \& Onate, M. (1986). Strong ground motion from the Michoacan, Mexico, earthquake. Science, 233, 1043-1049. https://doi.org/10.1126/science.233.4768.1043.

Andrews, D.J. (1986). Objective determination of source parameters and similarity of earthquakes of different size. Washington DCAmerican Geophysical Union Geophysical Monograph Series. 37. 259-267. https://doi.org/10. 1029/GM037p0259.

Apostolidis P., Raptakis D., Roumelioti Z., \& Pitilakis K. (2004). Determination of S wave velocity structure using microtremors and SPAC method applied in Thessaloniki (Greece). Soil Dynamics and Earthquake Engineering, 24(1), 49-67. https://doi.org/10.1016/j.soildyn.2003. 09.001 .
Astroza, M., \& Monge, J. (1996). Effect of site conditions on the seismic intensity. 11th World conference on earthquake engineering, Acapulco, Mexico (pp. 937-942).

Bac, T.V., Toan, D.V., Phong, L.H., \& Vu, T.A. (2011). Site condition on the western urban area of Hanoi city. Vietnam Journal of Earth Sciences, 33(3B) 567-572.

Bard, P.Y. (1994). Effects of surface geology on ground motion: Recent results and remaining issues. Proc. of the 10th European conference on earthquake engineering, Vienna (Vol. 1, pp. 305-323).

Bard, P.Y. (1999). Local effects on strong ground motion: physical basis and estimation methods in view of microzoning studies. Proc. of the Advances Study Course "Seismotectonic and Microzonation techniques in Earthquake Engineering: Integrated Training in Earthquake risk reduction practices» (pp. 75-124).

Bard, P.Y., \& Riepl-Thomas, J. (2000). Wave propagation in complex geological structures and their effects on strong ground motion. In: Kausel, E., Manolis, G. (Eds.), Wave Motion in Earthquake Engineering (Chapter 2, pp. 37-95). WIT Press.

Beck, J.L., \& Hall, J.F. (1986). Factors contributing to the catastrophe in Mexico City during the earthquake of September 19, 1985. Geophysical Research Letters, 13, 593-596. https://doi.org/10.1029/GL013i006p00593.

Biggs, J.M. (1964). Introduction to Structural Dynamics. New York: McGraw-Hill College, $341 \mathrm{p}$.

Bielak, J., Xu, J., Ghattas, O. (1999). Earthquake ground motion and structural response in Alluvial Valleys. Journal of Geotechnical and Geoenvironmental Engineering, 125(5), 413423. https://doi.org/10.1061/(ASCE)1090-0241 (1999)125:5(413).

Bielak, J., Hisada, Y., Bao, H., Xu, J., \& Ghattas, O. (2000). One- vs two- or three-dimensional effects in sedimentary valleys. Proc. of 12 th World Conference on Earthquake Engineering, New Zealand, February. Paper No. 2689. 
Boore, D.M. (2003). Simulation of ground motion using the stochastic method. Pure and Applied Geophysics, 160(3-4), 635-676. https://doi. org/10.1007/PL00012553.

Borcherdt, R.D. (1970). Effects of local geology on ground motion near San Francisco Bay. Bulletin of the Seismological Society of America, $60,29-61$.

Borcherdt, R.D. (1994). Estimates of Site-dependent response spectra for design (methodology and justification). Earthquake Spectra, 10(4), 617-653. https://doi.org/10.1193/1.1585791.

Borcherdt, R.D., \& Gibbs, J.F. (1976). Effects of local geological conditions in the San Francisco Bay region on ground motions and the intensities of the 1906 earthquake. Bulletin of the Seismological Society of America, 66(2), 467-500.

Borcherdt, R.D., \& Glassmoyer, G. (1994). Influences of local geology on strong and weak ground motions recorded in the San Francisco Bay region and their implications for sitespecific building-code provisions. In The Loma Prieta earthquake of October 17, 1989 - Strong Ground Motion (pp. 77-108). Publisher: U.S. Geological Survey Prof. Paper 1551-A.

Brady, A.G. (1966). Studies of Response to Earthquake Ground Motion. PhD Thesis. California Institute of Technology. Pasadena, California.

Calvi G.M., Pinho R., Magenes G., Bommer J.J., Restrepo-Vélez, L.F., \& Crowley H. (2006). Development of seismic vulnerability assessment methodologies over the past 30 years. Journal of Earthquake Technology, 43(3), 75-104.

Chávez-García, F.J. (2003). Site effect in Parkway basin: Comparison between observations and 3-D modeling. Geophysical Journal International, 154(3), 633-646. https://doi. org/10.1046/j.1365-246X.2003.02055.x.

Chávez-García, F.J., Raptakis D., Makrab K., \& Pitilakis K. (2000). Site effects at EuroseistestII. Results from 2-D numerical modeling and comparison with observations. Soil Dynamics and Earthquake Engeeniring, 19(1), 23-39. doi:10.1016/S0267-7261(99)00026-3.

Chávez-García, F.J., Rodríguez, M. \& Stephen- son, W.R. (2005). An alternative approach to the SPAC analysis of microtremors: exploiting stationarity of noise. Bulletin of the Seismological Society of America, 95, 277-293.

Ching, J.Y., \& Glaser, S.D. (2001). 1-D TimeDomain Solution for Seismic Ground Motion Prediction. Journal of Geotechnical and Geoenvironmental Engineering, 127(1), 36-47. https://doi.org/10.1061/(ASCE)1090-0241(20 01)127:1(36).

Dhakal, Y.P., \& Yamanaka, H. (2013). An evaluation of 3-D velocity models of the Kanto basin for long-period ground motion simulations. Journal of Seismology, 17, 1073-1102. https:// doi.org/10.1007/s10950-013-9373-4.

Dobry, R., Oweis I., \& Urzua A. (1976). Simplified procedures for estimating the fundamental period of a soil profile. Bulletin of the Seismological Society of America, 66, 1293-1321.

Duong, N.A., Nguyen, P.D., Tuan, V.M., Duan, B.V., \& Linh, N.T. (2017). Seismic hazard assessment and local site effect evaluation in Hanoi, Vietnam. Journal of Marine Science and Technology, 17(4B), 82-95. https://doi.org/10.15625/18 59-3097/17/4B/12996.

Ebrahimian, B. (2013). Simulation of Near-Field Strong Ground Motions Using Hybrid Method. In Engineering seismology, geotechnical and structural earthquake engineering (pp. 53-77). Publisher InTech. http//dx.doi. org/10.5772/55682.

Eurocode 8: Design of structures for earthquake resistance. Part 1: General rules, seismic actions and rules for buildings. (2004). European Committee for Standardization, Brussels, Belgium, $229 \mathrm{p}$.

Evernden, J.F., \& Thomson, J.M. (1985). Predicting seismic intensities. In Evaluating earthquake hazards in the Los Angeles region-An earth-science perspective (pp. 151-202). U.S. Geological Survey Professional Paper 1360.

Fäh, D., Iodice, C., Suadolc, P., \& Panza, G.F. (1993). A new method for the realistic estimation of seismic ground motion in megacities: the case of Rome. Earthquake Spectra, 9, 643668. https://doi.org/10.1193/1.1585735. 
Fernández, J.A. (2007). Numerical Simulation of Earthquake Ground Motions in the Upper Mississippi Embayment. Doctoral Dissertation. Georgia Institute of Technology, Atlanta.

Field, E.H., \& Jacob, K. (1995). A comparison and test of various site response estimation techniques, including three that are non-reference-site dependent. Bulletin of the Seismological Society of America, 85, 1127-1143.

Fiorentino, G., Nuti, C., Squeglia, N., Lavorato, D., \& Stacul, S. (2018). One-Dimensional Nonlinear Seismic Response Analysis Using StrengthControlled Constitutive Models: The Case of the Leaning Tower of Pisa's Subsoil. Geosciences, 8(7), 228. https://doi.org/10.3390/geosciences8070228.

Fletcher, J.B., \& Wen, K.L. (2005). Strong Ground Motion in the Taipei Basin from the 1999 ChiChi, Taiwan, Earthquake. Bulletin of the Seis mological Society of America, 95(4), 14281446. https://doi.org/10.1785/0120040022.

Frankel, A., Thorne, P., \& Rohay, A. (2014). Threedimensional ground-motion simulations of earthquakes for the Hanford area. Washington: U.S. Geological Survey Open-File Report 2013-1289, 48 p. doi:10.3133/ofr20131289.

Groholski, D.R., Hashash, Y.M.A., Kim, B., Musgrove, M., Harmon, J., \& Stewart, J. (2016). Simplified Model for Small-Strain Nonlinearity and Strength in 1-D Seismic Site Response Analysis. Journal of Geotechnical and Geoenvironmental Engineering, 142(9). https://doi. org/10.1061/(ASCE)GT.1943-5606.0001496.

Groholski, D.R., Hashash, Y.M.A., Musgrove, M., Harmon, J., \& Kim, B. (2015). Evaluation of 1-D Non-linear Site Response Analysis using a General Quadratic/Hyperbolic StrengthControlled Constitutive Model. Proc. of the 6th International Conference on Earthquake Geotechnical Engineering, Christchurch, New Zealand, 1-4 November 2015.

Gutenberg, B., \& Richter, C.F. (1956). Earthquake magnitude, intensity, energy, and acceleration: (Second paper). Bulletin of the Seismological Society of America, 46(2), 105-145.

Hadjian, A.H. (2002). Fundamental period and mode shape of layered soil profiles. Soil Dy- namics and Earthquake Engineering, 22, 885891. https://doi.org/10.1016/S0267-7261(02)00 111-2.

Haney, M.M., Mikesell, T.D., van Wijk, K., \& Nakahara, H. (2012). Extension of the spatial autocorrelation (SPAC) method to mixed-component correlations of surface waves. Geophysical Journal International, 191(1), 189-206. https://doi.org/10.1111/j.1365-246X.2012.05 597.x.

Hasal, M.E., Iyisan, R., \& Yamanaka, H. (2018). Basin edge effect on seismic ground response: a parametric study for Duzce basin case, Turkey. Arabian Journal for Science and Engineering, 43(4), 2069-2081. https://doi.org/10.1007/s13 369-017-2971-7.

Henstridge, J.D. (1979). A signal processing method for circular arrays. Geophysics, 44(2), 179184. https://doi.org/10.1190/1.1440959.

Herrera, I. (1984). Boundary Methods: An Algebraic Theory, Applicable Mathematics Series. Pitman (Advanced Publishing Program), Boston, MA.

Hill, M.P., \& Rossetto, T. (2008). Do existing damage scales meet the needs of seismic loss estimation? Proc. of the 14th World Conference on Earthquake Engineering (pp. 1-8).

Idriss, I.M., (1966). Response of Earth Banks during Earthquakes. Ph.D. Thesis. University of California, Berkeley.

Idriss, I.M., \& Seed, H.B. (1968). Seismic response of horizontal soil layers. Journal of the Soil Mechanics and Foundations Division, 94 (SM4), 1003-1031.

International Code Council, International Building Code. (2009). Publications, 4051 West Flossmoor Road, Country Club Hills, IL 60478, USA.

Kagami, H., Okada, S., \& Ohta, G. (1988). Versatile application of dense and precision seismic intensity data by an advanced questionnaire survey. Proc. of the ninth world conference on earthquake engineering Tokyo-Kyoto, Japan (pp. 937-942).

Kagami, H., Okada, S., Takai, N., \& Murakami, H. 
(1995). Seismic zonation maps of Sapporo metropolitan area, Northern Japan, derived from dense questionnaire surveys of seismic intensity. Proc. of the 5th Intern. Conf. Seismic Zonation (pp. 1043-1050).

Kamal, \& Narayan, J.P. (2015). 3-D basin-shape ratio effects on frequency content and spectral amplitudes of basin-generated surface waves and associated spatial ground motion amplification and differential ground motion. Journal of Seismology, 19(2), 293-316. https:// doi.org/10.1007/s10950-014-9466-8.

Kamalian, M., Jafari, M.K., Sohrabi-Bidar, A., Razmkhah, A., \& Gatmiri, B. (2006). Time-domain two-dimensional site response analysis of non-homogeneous topographic structures by a hybrid BE/FE method. Soil Dynamics and Earthquake Engineering, 26(8), 753-765. https:// doi.org/10.1016/j.soildyn.2005.12.008.

Kausel, E., \& Roesset, J.M. (1984). Soil Amplification; some refinements. Soil Dynamics and Earthquake Engineering, 3(3), 116-123. https: //doi.org/10.1016/0261-7277(84)90041-X.

Kawase, H. (2003). Site Effects on Strong Ground Motions. In W.H. Lee, H. Kanamori, P.C. Jennings, \& C. Kisslinger (Eds.), International Handbook of Earthquake and Engineering Seismology, Part B (pp. 1013-1030). Academic Press.

Kramer, S.L. (1996). Geotechnical Earthquake Engineering. Upper Saddle River, N. J. Prentice Hall International Series in Civil Engineering and Engineering Mechanics, 653 p.

Kudo, K., Kanno, T., Okada, H., Ozel, O., Erdik, M., Sasatani, T., Higashi, S., Takahashi, M., \& Yoshida, K. (2002). Site-specific issues for strong motions during the Kocaeli, Turkey earthquake of 17 August 1999, as inferred from Array observations of microotremors and aftershocks. Bulletin of the Seismological Society of America, 92, 448-465. https://doi.org/10.1785/0120000 812.

Langston, C.A. (1979). Structure under Mount Rainier, Washington, inferred from teleseismic body waves. Journal of Geophysical Research, 84(NB9), 4749—4762. https://doi.org/10.1029/ JB084iB09p04749.

Lee, S.J., Chen H.C., Liu Q., Komatitsch D., Hu- ang B.S., \& Tromp J. (2008). Three-dimensional simulations of seismic-wave propagation in the Taipei basin with realistic topography based upon the spectralelement method. Bulletin of the Seismological Society of America, 98, 253264. https://doi.org/10.1785/0120070033.

Lermo, J., \& Chávez-Garcia F.J. (1993). Site effect evaluation using spectral ratios with only one station. Bulletin of the Seismological Society of America, 83, 1574-1594.

Lermo, J., Rodriguez, M., \& Singh, S.K. (1988). The Mexico Earthquake of September 19, 1985 - Natural Period of Sites in the Valley of Mexico from Microtremor Measurements and Strong Motion Data. Earthquake Spectra, (4), 805-814. https://doi.org/10.1193/1.1585503.

Malla, S., Karanjit, S., Dangol, P., \& Gautam, D. (2019). Seismic Performance of High-Rise Condominium Building during the 2015 Gorkha EarthquakeSequence. Buildings, 9(2), 36. https: //doi.org/10.3390/buildings9020036.

Manolis, G.D., \& Beskos, D.E. (1988). Boundary Element Methods in Elastodynamics. Unwin Hyman Publishing, London.

Mavroeidis, G.P., Papageorgiou, A.S. (2003). A mathematical representation of near-fault groundmotions. Bulletin of the Seismological Society of America, 93(3), 1099-1131. https://doi. org/10.1785/0120020100.

Medvedev, S.V. (1962). Engineering Seismology. Moscow: AkademiaNauk Press, 283 p. (in Russian)

Midorikawa, S. (1987). Prediction of isoseismal map in the Kanto plain due to hypothetical earthquake. Journal of Structural Engineering, $33 B, 43-48$.

Minh L.H. et al., (2017). Study of the impact of seismotectonics on the stability of Song Tranh 2 hydropower dam in North Tra My, Quang Nam province. Final report of Nation project on science research. Institute of Geophysics, Vietnam (in Vietnamese).

Mogi, K. (1995). Earthquake Prediction Research in Japan. Journal of Physics of the Earth, 43(5), 533-561. https://doi.org/10.4294/jpe19 52.43.533. 
Moreno Murillo, J.M. (1995). The 1985 Mexico Earthquake (pp. 5-19). Geofisica Colombiana Universidad Nacional de Colombia.

Motazedian, D., Banab K., Hunter J., Sivathayalan S., Crow H., \& Brooks, G. (2011). Comparison of site periods derived from different evaluation methods. Bulletin of the Seismological Society of America, 101, 2942-2954. https://doi.org/10.1785/0120100344.

Nakamura, Y. (1989). Amethod for dynamic characteristics estimation of subsurface using microtremor on the ground surface. Railway Technical Research Institute, Quarterly Repports, $30(1), 25-33$.

Nakamura, Y. (1996). Real-time information systems for seismic hazards mitigation UrEDAS, HERAS and PIC. Railway Technical Research Institute, Quarterly Repports, 37(3), 112-127.

Nakamura, Y. (2019). What is the Nakamuara method? Seismological Research Letters, 90(4), 1437 - 1443. https://doi.org/10.1785/0220180 376.

Narayan J.P. (2005). Study of basin-edge effects on the ground motion characteristics using 2.5-D modeling. Pure and Applied Geophysics, 162, 273-289. https://doi.org/10.1007/s000 24-004-2600-8.

Narayan, J.P., \& Sahar, D. (2014). Three-dimensional viscoelastic finite-difference code and modelling of basement focusing effects on ground motion characteristics. Computational Geosciences, 18, 1023-1047. https://doi.org/10.10 07/s10596-014-9442-y.

Nguyen, P.D. (2002). Evaluation of site effect on strong ground motion. Thesis for the degree Master of Science. Hanoi University of Sciences (in Vietnamese).

Nguyen, P.D., \& Thang, N.C. (2012). An Investigation of topography effects on seismic ground motions. Vietnam Journal of Earth SCiences, 34(3), 281-286 (in Vietnamese).

Okada, H. (1998). Microtremors as an exploration method, geo-exploration handbook. Society of Exploration Geophysicists of Japan, 2, 203-211.

Okada, H. (2006). Theory of efficient array obser- vations of microtremors with special reference to the SPAC method. Exploration Geophysics, 37, 73-85. https://doi.org/10.1071/eg06073.

Okada, Y. (2013). Recent progress of seismic observation networks in Japan. Journal of Physics Conference Series, 433(1), 2039. https://doi. org/10.1088/1742-6596/433/1/012039.

Olsen, K.B. (2000). Site Amplification in the Los Angeles Basin from Three-Dimensional Modeling of Ground Motion. Bulletin of the Seismological Society of America, 90(6B), S77S94. https://doi.org/10.1785/0120000506.

Phuong, N.H. et al. (2002). Study on the seismic risk assessment for Hanoi. Final report of scientific research funding program supported by Hanoi city government, ID: 01C-04. Institute of Geophysics, Institute of Science and Technology (in Vietnamese).

Phuong, N.H. et al. (2006). Urban earthquake risk analysis and engineering applications. $\mathrm{Vi}$ etnam Journal of Earth Sciences, 22(3), 210221 (in Vietnamese).

Pitarka, A., Irikura, K., Iwata, T., \& Sekiguchi, H. (1998). Three dimensional simulation of the near fault ground motion for 1995, Hyogo-ken Nanbu (Kobe), Japan earthquake. Bulletin of the Seismological Society of America, 88, 428440.

Priolo, E., Pacor, F., Spallarossa, D. et al., (2019). Seismological analyses of the seismic microzonation of 138 municipalities damaged by the 2016-2017 seismic sequence in Central Italy. Bulletin of Earthquake Engineering. https://doi. org/10.1007/s10518-019-00652-x.

Riepl,J.,Zahradník, J.,Plicka, V., \&Bard, P.Y.(2000). About the Efficiency of Numerical 1-D and 2-D Modelling of Site Effects in Basin Structures. Pure and Applied Geophysics, 157, 319-342. https://doi.org/10.1007/s000240050002.

Romão, X., Costa, A.A., Pauperio, E., Rodrigues, H., Vicente, R., Varum, H., \& Costa, A. (2013). Field observations and interpretation of the structural performance of constructions after the 11 May 2011 Lorca earthquake. Engineering Failure Analysis 34, 670 - 692. https://doi. org/10.1016/j.engfailanal.2013.01.040. 
Ground Motion. Soil Dynamics and Earthquake Engineering, 6(2), 124-132. https://doi.org /10.1016/0267-7261(87)90022-4

Sánchez-Sesma F.J., \& Crouse C.B. (2015). Effects of site geology on seismic ground motion: early history. Earthquake Engineering \& Structural Dynamics, 44(7), 1099-1113. https:// doi.org/10.1002/eqe.2503.

Schnabel, P.B., Lysmer, J., \& Seed, H.B. (1972). SHAKE: A computer program for earthquake response analysis of horizontally layered sites. Report No. EERC 72-12, Earthquake Engineering Research Center, University of California, Berkeley, California.

Seo, K., Yamanaka, H., Kurita, K., Motoki, K., Eto, K., Terasaka, M., \& Kobayashi, H. (2000). Ajoint research on microtremors in Fukui basin, Japan - for site effects evaluation during the 1948 Fukui (Japan) earthquake. 12 WCEE 2000, New Zealand.

Shima, E. (1962). Modifications of Seismic Waves in Superficial Layers as Verified by Comparative Observations on and Beneath the Surface. Bulletin of the Earthquake Research Institute, Tokyo Univ. 40, 187-259.

Shima, E. (1978). Seismic microzoning map of Tokyo. Proc. of the Second International Conference on Seismic Zonation (Vol. I, pp. 433443).

Shin, T.C., Teng, T. (2001). An Overview of the 1999 Chi-Chi, Taiwan, Earthquake. Bulletin of the Seismological Society of America, 91(5), 895-913. https://doi.org/10.1785/0120000738.

Smerzini, C., Paolucci, R., \& Stupazzini, M. (2011 a). Comparison of 3-D, 2-D and 1-D numerical approaches to predict long period earthquake ground motion in the Gubbio plain, Central Italy. Bulletin of Earthquake Engineering, 9, 2007-2029. https://doi.org/10.1007/s10 518-011-9289-8.

Smerzini, C., Paolucci, R., \& Stupazzini, M. (2011b). Numerical simulations of seismic response at Gubbio basin, central Italy. TC 203 Conferences in Earthquake Engineering - 5th International Conference on Earthquake Geotechnical Engineering (Santiago, Chile).

Son, L.T. (2003). Study on earthquake prediction and ground motion in Vietnam. Final report of the National project 2003, Institute of Geophysics, Institute of Science and Technology (in Vietnamese).

Son, L.T. (2007). Microzoning map of the Dien Bien city. Vietnam Journal of Earth Sciences, 29(1), 68-82 (in Vietnamese).

Stanko, D., Markušić, S., Gazdek, M., Sanković, V., Slukan, I. \& Ivančić, I. (2019). Assessment of the Seismic Site Amplification in the City of Ivanec (NW Part of Croatia) Using the Microtremor HVSR Method and Equivalent-Linear Site Response Analysis. Geosciences, 9(7), 312. https: //doi.org/10.3390/geosciences9070312.

Steidl, J.H., Tumarkin A.G., \& Archuleta R. (1996). What is a reference site? Bulletin of the Seismological Society of America, 86(6), 1733-1748.

Thompson, W.T. (1950). Transmission of Elastic Waves through a Stratified Solid Medium. Journal of Applied Physics, 21, 89-93. https:// doi.org/10.1063/1.1699629.

Thuy, N.N. et al. (2004). Study, supplement and enhancement of the $1: 25.000$ scale seismic microzonning map of the enlarged Hanoi city, development of the ground motion characteristics database in Hanoi in accordance with the map. Final report of the scientific research project. The Hanoi Institute of Building Technology, Hanoi Construction Department (in Vietnamese).

Tramelli, A., Galluzzo, D., Del Pezzo, E., \& Di Vito, M.A. (2010). A detailed study of the site eects in the volcanic area of CampiFlegrei using empirical approaches. Geophysical Journal International, 182(2), 1073-1086. https://doi. org/10.1111/j.1365-246X.2010.04675.x.

Trifunac M.D. (2016). Site conditions and earthquake ground motion - Areview. Soil Dynamics and Earthquake Engineering, 90, 88-100. https://doi.org/10.1016/j.soildyn.2016.08.003.

Trifunac, M.D. (1971). Surface motion of a semicylindrical alluvial valley for incident plane SH waves. Bulletin of the Seismological Society of America, 61(6), 1755-1770.

Trifunac, M.D., \& Brady, A.G. (1975). A Study on the Duration of Strong Earthquake Ground Mo- 
tion. Bulletin of the Seismological Society of America, 65(3), 581-626.

Trung, G.K., Vinh, N.D., \& Men, D.T. (2018). Soil Classification and Seismic Site Response Analysis for Some Areas in Hanoi City. VNU Journal of Science: Earth and Environmental Sciences, 34(1), 37-44.

Tuan, V.M., Vinh, N.D., Duong, N.A., Minh, N.S., Thang, N.C., \& Nguyen, P.D. (2012). The H/V ratio method and its abilities in estimation of the site effects on strong ground motions in Hanoi. Vietnam Journal of Earth Sciences, 34(1), 70-75 (in Vietnamese).

Urzua, A., Dobry, R., \& Christian, J. (2017). Is harmonic averaging of shear wave velocity or the simplified Rayleigh method appropriate to estimate the period of a soil profile. Earthquake Spectra, 33, 895-915. https://doi.org/10.1193/ 101716EQS174M.

Vietnam Building Code. (2012) TCVN 93862012. Design of structures for earthquake resistances-Part 1: General rules, seismic actions and rules for buildings.

Vijayendra, K.V., Nayak, S., \& Prasad, S.K. (2015). An alternative method to estimate fundamental period of layered soil deposit. Indian Geotechnical Journal, 45, 192-199. https://doi. org/10.1007/s40098-014-0121-7.

Wen, K.L., \& Huang, J.Y. (2012). Dense Microtremor Survey for Site Effect Study in Taiwan. Proc. of the 15th World Conference of Earthquake Engineering, Lisbon.

Wen, K.L., \& Hung, N.T. (2011). Seismic microzoning map of Hanoi city on the basis of microtremor motion observations. Vietnam Journal of Earth Sciences, 33(2), 175-184 (in Vietnamese).

Wang, S.Y., Shi Y., Jiang W.P., Yao E.L., \& Miao Y. (2018). Estimating Site Fundamental Period from Shear-Wave Velocity Profile. Bulletin of the Seismological Society of America, 108(6), 3431-3445. https://doi.org/108.10.1785 /0120180103.

Whitman, R.V. (1973). Damage Probability Matrices for Prototype Buildings. Department of $\mathrm{Ci}$ vil Engineering. Research Report R73-57. Mas- sachusetts Institute of Technology, Cambridge, Massachusetts.

Whitman, R.V., Anagnos, T., Kircher, C.A., Lagorio, H.J., Lawson, R.S., \& Schneider, P. (1997). Development of a National Earthquake Loss Estimation Methodology. Earthquake Spectra, 13(4),643 - 661.https://doi.org/10.1193/1.1585973.

Wong, H.L., \& Trifunac, M.D. (1974). Surface Motion of a Semi-Elliptical Alluvial Valley for Incident Plane SH Waves. Bulletin of the Seismological Society of America, 64(5), 1389 -1408.

Wu, Y.M., Chen, C.C., Shin, T.C., Tsai, Y.B., Lee, W.H.K., \& Teng, T.L. (1997). Taiwan Rapid Earthquake Information Release System. Seismological Research Letters, 68(6), 931-943. https://doi.org/10.1785/gssrl.68.6.931.

Wu, Y.M., Mittal, H., Huang, T.C., Yang, B.M., Jan, J.C., \& Chen, S.K. (2019). Performance of a Low-Cost Earthquake Early Warning System (P-Alert) and Shake Map Production during the 2018 Mw 6.4 Hualien, Taiwan, earthquake. Seismological Research Letters, 90(1), 19-29. https://doi.org/10.1785/0220180170.

Xuyen, N.D., Thuy, N.N. et al. (1996). Database of solutions for seismic hazard mitigation in Vietnam - Part II: Earthquake zoning for Vietnam. Final report of the National project KT-ĐL 92-07, 1992-1996, Institute of Geophysics, Institute of Science and Technology (in Vietnamese).

Xuyen, N.D. et al. (2004). Study of earthquake prediction and ground motion in Vietnam. Final report of the National project 2000-2004, Institute of Geophysics, Institute of Science and Technology (in Vietnamese).

Yamanaka, H., Dravinski, M., \& Kagami, H. (1993). Continuous measurements of microtremors on sediments and basement in Los Angeles, California. Bulletin of the Seismological Society of America, 83(5), 1595-1609.

Yamin, L.E., Reyes, J.C., Rueda, R., Prada, E., Rincon, R., Herrera, C., Daza, J., \& Riaño, A.C. (2018). Practical seismic microzonation in complex geological environments. Soil Dynamics and Earthquake Engineering, 114, 480-494. https: //doi.org/10.1016/j.soildyn.2018.07.030.

Zhao, B., Taucer, F., \& Rossetto, T. (2009). Field 
investigation on the performance of building structures during the 12 May 2008 Wenchuan Earthquake in China. Engineering Structures, 31(8), 1707-1723. https://doi.org/10.1016/j. engstruct.2009.02.039.

Zhao, J.X. (1996). Estimating modal parameters for a simple soft-soil site having a linear distribution of shear wave velocity with depth. Earthquake Engineering \& Structural Dynamics, 25(2), 163-178. https://doi.org/10.1002/ (SICI)1096-9845(199602)25:2<163::AID-EQ E544>3.0.CO;2-8.

\title{
Обзор методов сейсмических реакций грунта в мире и применение их во Вьетнаме
}

\author{
Г.К. Трунг, Н.А. Винь, 2021 \\ Физический факультет, Университет науки, Вьетнамский национальный \\ университет, Ханой, Вьетнам
}

Оценка влияния землетрясений на строения и мегаструктуры на больших городских пространствах чрезвычайно важна. Поэтому она всегда привлекает внимание проектировщиков конструкций и политиков, вовлеченных в программу строительных норм. Когда происходит землетрясение, колебание передается строительным площадкам. Хотя интенсивность колебания вначале не слишком велика, движение, вероятно, становится сильнее и длится дольше при особых условиях местной площадки. Знаменитые примеры такого влияния - события, которые произошли в г. Мехико в 1985 г. и на Тайване в 1999 г. Известны многочисленные подходы к этой проблеме, такие как оценки по сейсмическим полевым наблюдениям, метод микросотрясений, методы, использующие данные слабых подвижек, данные сильных движений, одномерный метод анализа распространения волны или трехмерноый метод аналыза распространение волны и др. Сделан обзор преимуществ и недостатков методов, применяемых в мировой практике. Проанализировано применение этих методов при исследованиях во Вьетнаме в целом и в г. Ханой в частности - в его западных районах и в нескольких точках городских участков. Приведены комментарии и оценки скорости сдвиговой волны, классифицирован тип грунта без детальной карты влияния локального положения на всю территорию города. Аля оценки всех локальных эффектов города, будущие исследования следует фокусировать на применении 1D анализа для его центральной зоны и комбинировать 1D анализ с 2D или 3D анализом, чтобы иметь большее представление о воздействии локальных эффектов. Указанный гибридный подход необходим для сравнения и верификации данных, полученных эмпирическим и аналитическим методами. Следует также обратить внимание на многие проблемы, например: создание детальной 3D геологической модели для г. Ханой, расчет доминантных периодов и укрепления местных грунтовых условий дмя городских зон.

Ключевые слова: усиление, обзор, влияние места работ, сильные подвижки грунта, условия местности. 


\title{
Огляд методів сейсмічних реакцій грунту в світі і застосування їх у В'єтнамі
}

\author{
Г.К. Трунг, Н.А. Вінь, 2021 \\ Фізичний факультет, Університет науки, В'єтнамський національний \\ університет, Ханой, В'етнам
}

\begin{abstract}
Оцінювання впливу землетрусів на будови і мегаструктури на великих міських просторах надзвичайно важливе. Тому воно завжди привертає увагу проєктувальників конструкцій і політиків, залучених до програми будівельних норм. Коли відбувається землетрус, коливання передається будівельним майданчикам. Хоча інтенсивність коливання спочатку не дуже велика, рух, імовірно, стає сильнішим і триває довше за особливих умов місцевого майданчика. Знаменитими прикладами такого впливу є події, що відбулися у м. Мехіко в 1985 р. і на Тайвані в 1999 р. Існують численні підходи до цієї проблеми, такі як оцінювання за сейсмічними польовими спостереженнями, метод мікрострясань, методи, що використовують дані слабких посувань, дані сильних рухів, одновимірний метод аналізу поширення хвилі або тривимірного поширення хвилі та ін. Зроблено огляд переваг і недоліків методів, які звичайно застосовують у світі. Проаналізовано застосовання цих методів у дослідженнях, проведених у В'єтнамі в цілому і в м. Ханой зокрема - переважно у західних районах міста і в кількох точках міських ділянок. Наведено коментарі та оцінки швидкості зсувної хвилі, класифіковано тип грунту без детальної карти впливу локального положення на всю територію міста. Аля оцінювання всіх локальних ефектів міста майбутні дослідження слід фокусувати на застосуванні 1D аналізу Аля його центральної зони і комбінувати 1D аналіз з 2D або 3D аналізом, щоб мати ліпше уявлення про вплив локальних ефектів. Цей гібридний підхід необхідний для порівняня і верифікації даних, отриманих емпіричним і аналітичним методами. Слід також звернути увагу на багато проблем, наприклад: створення детальної 3D геологічної моделі для м. Ханой, розрахунок домінантних періодів і зміцнення місцевих грунтових умов Аля міських зон.
\end{abstract}

Ключові слова: посилення, огляд, вплив місця робіт, сильні посування грунту, умови місцевості. 